\title{
Conjugal exposure to polychlorinated biphenyls (PCBs)
}

\author{
A FISCHBEIN, MARY S WOLFF \\ From the Division of Environmental and Occupational Medicine, Department of Community Medicine, Mount \\ Sinai School of Medicine of the City University of New York, New York 10029, USA
}

Polychlorinated biphenyls (PCBs) are a group of chlorinated aromatic hydrocarbons that have attracted much public health attention. Having been used in industry since the 1930s, PCBs were found to be almost ubiquitous in the environment by $1966 .^{1}$ Owing to their excellent dielectric and insulating properties, PCBs have been used in transformers and capacitors, hydraulic systems, paints and other surface coatings, and as a constituent in carbonless copying paper. Manufacture of PCBs was discontinued in the United States in 1977 because of concern over potential adverse health effects. Their use, storage, and disposal have subsequently been strictly regulated. 2

Adverse health effects from accidental exposure to PCBs and their toxic contaminants, notably polychlorinated dibenzofurans (PCDFs), have been reported from Japan and Taiwan in connection with two episodes involving ingestion of contaminated rice cooking oil. The clinical syndromes, known as "yusho" (Japanese: oil disease) and "yu-cheng" (Chinese: oil disease) included chloracne, abnormalities in liver function in severely affected subjects, and raised concentrations of serum triglycerides. ${ }^{3}$ More recent studies of occupationally exposed populations have reported less severe clinical manifestations despite the presence of high serum concentrations of PCBs. ${ }^{4}$

In 1935 chloracne was reported in family members of a worker employed in a factory in which chlorinated biphenyls and chlorinated naphthalenes were manufactured and it was suggested that household exposure had occurred through chemical laden clothes. ${ }^{5}$ In the present two cases there is analytical chemical evidence of transmission of PCBs from transformer maintenance workers to their wives.

\section{Case 1}

The patient, a 25 year old white man, was employedas a railway electrician for four years before his exam ination in 1979. His job consisted of repairing and: maintaining transformers and the handling ofe dielectric fluid containing PCBs. There was frequento skin contact with the fluid and the patient reported that he "smelled and tasted the chemical in his food.' His medical history showed surgical treatment of lef sided varicocele in 1977 and hypertension treatech with diuretics since 1978. His chief complaintso included excessive fatigue and skin abnormalities in the form of acneiform lesions on both thighs. Physica $\bar{b}$ examination in December 1979 confirmed the presence of several $1 \times 3 \mathrm{~mm}$ red maculopapules bilater ally on the thighs. No other dermatologica? abnormalities were seen. Full blood count and clinica biochemistry screens were normal. Serum PCBs weres analysed as previously reported, ${ }^{6}$ with calculations? performed according to the method of Webb and McCall $^{7}$ using Aroclor 1254 as the standard. Ino December 1979 the concentration was $101 \mathrm{ng} / \mathrm{mL}$, in February 1980, $94 \mathrm{ng} / \mathrm{mL}$, and in March 1982음 $69 \mathrm{ng} / \mathrm{mL}$. Adipose PCB concentration in 1980 was $20.7 \mathrm{ng} / \mathrm{mg}$ (parts per million). The PCB concen trations in serum and adipose tissue were considered raised compared with those observed in a genera $P$ population: $7 \mathrm{ng} / \mathrm{mL}$ serum and $1 \mathrm{ng} / \mathrm{mg}$ adipose tis- 0 sue reported from this laboratory comparable with values reported by other investigators. Pattern desig- nation was made using the method of Lea et al, 6 which we have applied to human serum samples. ${ }^{9}$ The PCB pattern corresponded to Aroclor 1254 ratheres than 1260. In addition, the concentration of peak " 125 " was greater than that of peak "146" in thiso patient, which is typical of exposure to Aroclor 1254 but not Aroclor 1260. 
The patient's wife, a 24 year old white woman, worked as a beautician from 1978 to 1979 ; she had no history of occupational exposure to PCBs. She reported that she laundered the overalls that her husband brought home from work. Her medical history was unremarkable and the results of physical examination, blood count, and biochemistry screening were normal. Serum concentration of PCBs was $13 \mathrm{ng} / \mathrm{mL}$ in $1979,15 \mathrm{ng} / \mathrm{mL}$ in 1980 , and $11 \mathrm{ng} / \mathrm{mL}$ in 1982; these differences are within experimental error. Her PCB pattern, like that of her husband, corresponded to Aroclor 1254.

\section{Case 2}

The patient, a 23 year old black man, was employed as a labourer and electrician at the same railway company as the first patient. He had been engaged in transformer maintenance for three years before the examination in 1980 and had also used asbestos in locomotive engine maintenance work for about five years. He handled dielectric fluid containing PCBs and wore gloves regularly but had used protective respiratory equipment only during the few months before the examination. He supplied his own work clothes which he brought home to his wife for laundering. His chief complaint included headaches and excessive fatigue even with normal sleep patterns. A few months before the examination he developed acneiform lesions on his legs and upper arms. Physical examination showed several pustules, some empty and dry with scaling, and hyperkeratotic areas surrounding the lesions on the anterior and lateral aspects of both upper arms and thighs. Blood count and serum biochemistry were normal. The serum PCB concentration was $77 \mathrm{ng} / \mathrm{mL}$ as Aroclor 1254 . The PCB content in adipose tissue obtained by fat biopsy showed a level of $17.4 \mathrm{ng} / \mathrm{mg}$ (parts per million) as Aroclor 1254. The pattern designation, as described for the previous two subjects, corresponded to Aroclor 1254.

A blood sample was also obtained from the patient's wife, who had no history of occupational exposure to PCBs, but she laundered her husband's work clothes. Her serum PCB concentration was $6 \mathrm{ng} / \mathrm{mL}$; adipose tissue was $3.9 \mathrm{ng} / \mathrm{mg}(\mathrm{ppm})$ with both having an Aroclor 1254 pattern.

\section{Comment}

The extension of occupational health hazards from the workplace to a worker's household is being increasingly documented and is a cause for concern. Family contacts should be considered a group "at risk" for developing adverse health effects due to the "carrying home" of disease causing agents present in the occupational environment. Both asbestos ${ }^{10}$ and lead related diseases ${ }^{11}$ have been reported in household contacts of exposed workers. Beryllium related hazards and diethylstilboesterol (DES) intoxication have also occurred in workers' families. ${ }^{12} 13$

Soon after PCBs had attained wide industrial use, chloracne was reported among children of workers employed in a facility manufacturing chlorinated biphenyl compounds and chlorinated naphthalenes, and it was suggested that the worker had transmitted the materials to his children during close contact at home. $^{5}$ In more recent investigations of workers occupationally exposed to PCBs clinical abnormalities have been rare even among those with direct occupational exposure, and the question whether household members of workers may be at risk of increased exposure has received only limited attention. ${ }^{14}$

In the course of the clinical evaluation of the two transformer maintenance workers reported here we found high serum and adipose PCB concentrations, dermatological abnormalities suggestive of but not specific for chloracne, and a gas chromatographic pattern that suggested occupational rather than environmental exposure. In addition to raised serum PCB concentrations, the observation of a PCB pattern resembling Aroclor 1254 indicated occupational exposure, since in our experience approximately $90 \%$ of non-industrially exposed individuals have been found to have patterns resembling Aroclor 1260 by the criteria described above. ${ }^{9}$ Moreover, we had the opportunity of examining the wives of the two workers, and despite the absence of clinical abnormalities and the lack of raised serum and adipose tissue concentration of PCBs, they had PCB patterns corresponding to Aroclor 1254 like those observed in their husbands.

Although adverse health effects of household exposure to PCBs are less likely to occur than those associated with similar exposure to asbestos, for example, it would seem prudent to take appropriate industrial hygiene measures to prevent the transmission of a chemical compound from the occupational environment to the household, especially those with children.

\section{References}

1 Jensen S. The PCB story. Ambio 1972;1:123-31.

2 Federal Register. Environmental Protection Agency. Polychlorinated biphenyls (PCBs); manufacturing, processing, distribution in commerce and use prohibition: use in closed and controlled manufacturing processes. Washington: EPA, 1982:46980-96.

3 Kuratsune M, Shapiro RE. PCB poisoning in Japan and Taiwan. Vol 137. Progress in clinical and biological research. New York: 
Alan R Liss, Inc, 1984.

4 Chase K, Wong O, Thomas D, Berney BW, Simon RK. Clinical and metabolic abnormalities associated with occupational exposure to polychlorinated biphenyls (PCBs). J Occup Med 1982;24:109-14.

5 Commonwealth of Pennsylvania. A preliminary report of the dermatological and systemic effects of exposure to hexachloronaphthalene and chlorodiphenyl. Harrisburg, PA: Bureau of Industrial Standards, Department of Labor and Industry, 1935. (Special bulletin 1935;43.)

6 Wolff MS, Anderson HA, Selikoff IJ. Human tissue burdens of halogenated aromatic chemicals in Michigan. JAMA 1982;247:2112-6.

7 Webb RG, McCall AC. Qualitative PCB standards for electron capture gas chromatography. $J$ Chromatogr Sci 1973;11:366-73.

8 Lea RE, Bramston-Cook R, Tschida J. Pattern recognition for identification and quantitation of complex mixtures in chromatography. Anal Chem 1983;55:626-9.
9 Wolff MS, Fischbein A, Rosenman KD, Levin SM. Pattern desig. nation of PCBs in human samples. Chemosphere 1986;15:301-7.

10 Anderson H, Lilis R, Daum S, Fischbein A, Selikoff IJ. Household exposure to asbestos and risk of subsequence disease. In Lemen R, Dement J, eds. Dusts and disease. Chicago: Pathotos Publishers Inc, 1979:145-56.

11 Watson WN, Witherell PE, Giguere MS. Increased lead absorp을 tion in children of workers in a lead storage battery plant. $\bar{p}$. Occup Med 1978;20:759-61.

12 Lieben J, Williams RR. Respiratory disease associated with beryl lium refining and alloy fabrication. 1968 follow-up. $J$ Occues Med 1969;11:480-5.

13 Klorfin I, Bartini B. Diethylstilbestrol intoxication in workers ip a pharmaceutical factory, members of their families and poulterer. Harefuah 1956;51:57-60.

14 Baker EL, Landrigan PJ, Glueck CJ, et al. Metabolic con sequences of exposure to polychlorinated biphenyls (PCBs) in sewage sludge. Am J Epidemiol 1980;112:553-63. 